Web Site: https://jutq.utq.edu.iq/index.php/main

Email: journal@jutq.utq.edu.iq

\title{
Photovoltaic Parameters Identification Using Optimization Algorithm https://doi.org/10.32792/utq/utj/vol12/2/5
}

\section{Dr. Issa Ahmed Abed \\ Engineering Technical College Basrah, Southern Technical University, Iraq Email:issaahmedabd80@yahoo.com}

\begin{abstract}
Solar energy is regarded as an essential source of electricity generation. It is one of the renewable energy sources that have the potential for future energy applications. The optimization algorithms, such as the Electromagnetism-like (EM) algorithm is suitable for tackling numerous optimization problems. The EM algorithm has the ability to handle nonlinear functions, and it is imagined to be extremely productive for the parameters estimation of a photovoltaic (PV) module. Different values of control parameters of the method have been tested in this paper. This is done to demonstrate the impact of every parameter on the performance of the algorithm regarding the speed of convergence and precision. In every case of parameters, the algorithm can extract the photovoltaic model parameters. The objective function for every arrangement of values has been resolved and then contrasted with others in order to select the best case.
\end{abstract}

Keywords: Solar energy, PV module, objective function, electromagnetismlike, control parameters.

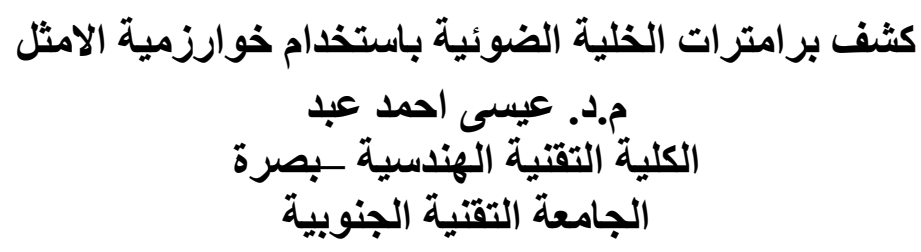




\section{University of Thi-Qar Journal Vol.12 No.2 June 2017 \\ Web Site: https://jutq.utq.edu.iq/index.php/main \\ Email: journal@jutq.utq.edu.iq}

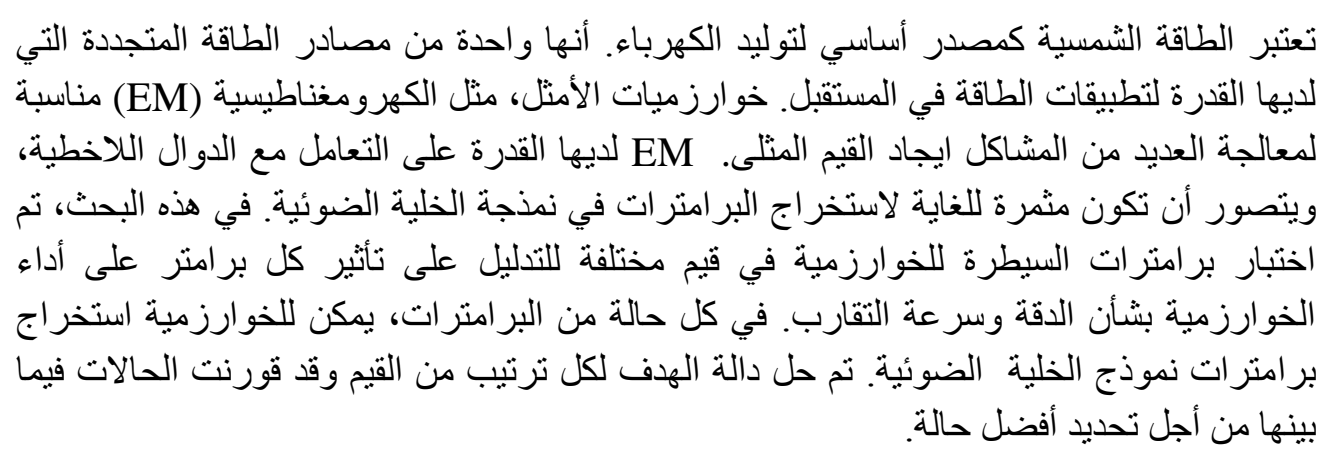

\section{Introduction}

Keeping in mind the end goal of enhancing the efficiency of solar energy systems, accurate representation of current versus voltage characteristics of solar cells has been the focus of much research work [1,2]. Parametric extraction of solar cell models assumes an essential part in the simulation and configuration figuring of photovoltaic (PV) frameworks. The fundamental downside in exact representation is the lack of accurate data on the parametric values, which undoubtedly portray the solar cell.

Oliva et al. [3] propose the utilization of the ABC (Artificial Bee Colony) algorithm to precisely determine the parametric values of solar cell. The algorithm mimics the intelligent foraging behavior of bees. When placed side by side with other approaches, $\mathrm{ABC}$ is definitely superior, especially when dealing with multimodal objective functions. The results also confirm its robustness and precisions vis-à-vis the suggested system.

Askarzadeh \& Coelho [4] attempted to analyze the parameters associated with the photovoltaic arrays via the usage of the heuristic technique. The utilization of an optimization method allowed us to gather the real electrical parameters that could be used to ascertain the nonlinearity of the I-V curves of photovoltaic modules. The Bird Mating Optimizer (BMO) is an algorithm derived from the mating behavior of multiple species of birds, and is primarily used to solve complicated optimization problems. They streamlined the initial BMO method and utilized it to determine the electrical parameters of the system for a formless silicon photovoltaic model at various working situations. The simplified version of the BMO gets rid of parametric settings 


\section{University of Thi-Qar Journal Vol.12 No.2 June 2017 \\ Web Site: https://jutq.utq.edu.iq/index.php/main \\ Email: journal@jutq.utq.edu.iq}

in the first BMO while likewise changing a few rules. Its usefulness is checked by comparing results from two particle swarm optimization variations, two harmony search variants and in addition seeker optimization algorithm.

This work discusses PV modelling in solar energy system using Electromagnetism-like (EM) algorithm as its optimization algorithm. The remainder of the paper is sorted out in the following order: Section 1 gives the topic; Section 2 points out common interests in PV modelling; Section 3 introduces the objective function; Section 4 is recorded the implementation of the EM algorithm; the simulation results are showcased in Section 5 and finally, Section 6 concludes the study.

\section{Photovoltaic Models}

\subsection{The Simplest Model}

The conduct of photovoltaic cells has always been depicted using models, such as the single diode lumped circuit model, which is quite ubiquitous [5]. The ideal representative of an equivalent circuit of a solar cell with a parallel source of current and a diode is depicted in Fig. 1 [6]. This model is preferred due to its balance of simplicity and precision $[7,8]$. The current source output is straightforwardly proportional to the light falling on the cell $\left(I_{P V}\right)$ [9], while the current source stands in for the current provided by photons (at times indicated as $I_{\mathrm{ph}}$ ), and its output is steady under constant incident radiation of light and temperature [10].

In order to create an accurate representative PV cell circuit, it is vital that the each cell's component's physical and electrical parameters be understood.

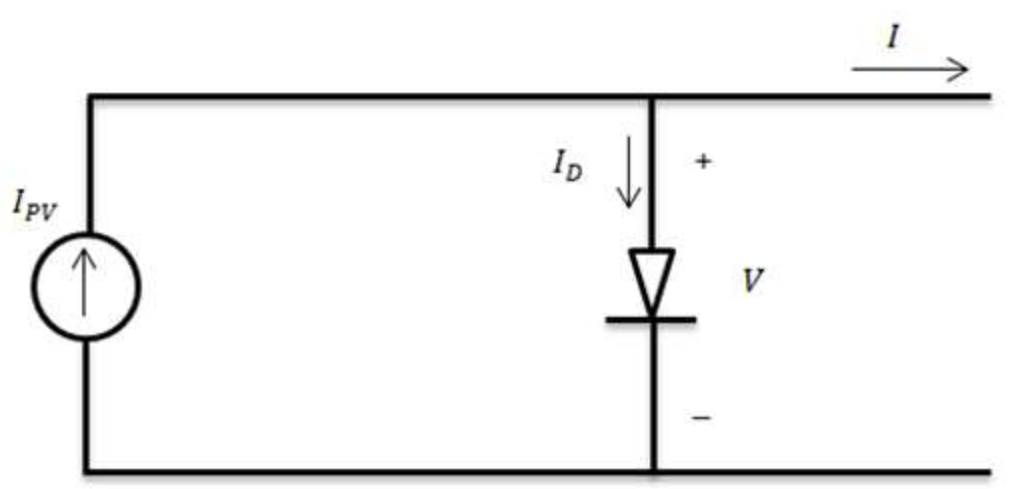




\section{University of Thi-Qar Journal Vol.12 No.2 June 2017 \\ Web Site: https://jutq.utq.edu.iq/index.php/main \\ Email: journal@jutq.utq.edu.iq}

Fig. 1 Ideal PV circuit model

The procedures of modeling the solar cell could theoretically be developed using the equations (1-3). The output current $I$ from the PV cell is determined via the application of the Kirchoff's current law (KCL) upon the simplified circuit demonstrated in Fig. 1 [10

$$
\begin{aligned}
& I=I_{P V}-I_{D} \\
& I_{D}=I_{O}\left[\exp \left(\frac{V}{a V_{T}}\right)-1\right]
\end{aligned}
$$

$I_{D}$ of the equation (1) can be replaced with equation (2), results in a representative I-V relationship of the PV cell [10].

$$
I=I_{P V}-I_{o}\left[\exp \left(\frac{V}{a V_{T}}\right)-1\right]
$$

where $I_{P V}$ is considered as the current produced by the incidence of light , $I_{D}$ is represented the current shunted through the intrinsic diode, while the voltage across the PV cell is $V, I_{O}$ is the reverse saturation current, $V_{T}$ which is equal to $(k T / q)$ acts the thermal voltage of the PV, $q$ is the electron charge $\left(1.60217646 \times 10^{-19} C\right), k$ is the Boltzmann constant $\left(1.3806503 \times 10^{-23} \mathrm{~J} / K\right), T$ is the temperature of the $\mathrm{p}$-n junction in $K$ (Kelvin), and $a$ is the diode ideality factor [10].

\subsection{The Precise Model}

There were a few factors that were not taken into account in the simplified model that would influence the performance of PV cells:

a) Series resistance: A collective series of resistance runs through the semiconductor component, metal grid, contacts, and current collecting 


\section{University of Thi-Qar Journal Vol.12 No.2 June 2017 \\ Web Site: https://jutq.utq.edu.iq/index.php/main \\ Email: journal@jutq.utq.edu.iq}

buses in a practical PV cell [11]. The collective losses are combined to create a series resistor $\left(R_{S}\right)$, and its resulting effect over PV module is rather pronounced, especially for the ones that is made up of numerous series-connected cells, where its resistance is amplified via multiplication with the total number of cells.

b) Parallel resistance or shunt resistance: It is defined as losses linked to minuscule leaks via a resistor that runs in parallel with an intrinsic device [11]. It could theoretically be pictured using a parallel resistor $\left(R_{p}\right)$. However, its effect upon the PV module is noticeably lesser than series resistance; it will only be obvious when a collection of PV modules is linked in parallel within much larger systems.

Equation (4) details the single diode model [12].

$$
I=I_{P V}-I_{o}\left[\exp \left(\frac{V+I R_{s}}{a V_{T}}\right)-1\right]-\left(\frac{V+I R_{s}}{R_{p}}\right)
$$

In equation (4), $R_{S}$ is the module equivalent series resistance, while the equivalent parallel resistance is $R_{p}$.

\subsection{A Photovoltaic Module}

A collection of combined PV cells results in PV modules. Universally speaking, the $1 / 2 \mathrm{~V}$ produced by a single cell is inadequate. In order to address this problem, the cells are linked to one another in series to increase output, while others could be arranged in parallel to increase current outputs [9]. Equation (4) will be converted to [13]:

$$
I=I_{P V}-I_{o}\left[\exp \left(\frac{V+I R_{s}}{a N_{s} V_{T}}\right)-1\right]-\left(\frac{V+I R_{s}}{R_{p}}\right)
$$

where $N_{S}$ is the number of cells in the module.

\section{Objective Function}

The objective function is the root mean square error (RMSE), as shown in equations (6-8) [13].

$$
\begin{aligned}
& \operatorname{Obj}(\text { pars })=\sqrt{\frac{1}{N} \sum_{k=1}^{N} f_{k}(V, I, \text { pars })^{2}} \\
& f(V, I, \text { pars })=I_{P V}-I_{o}\left[\exp \left(\frac{V+I R_{s}}{a N_{s} V_{t}}\right)-1\right]-\left(\frac{V+I R_{s}}{R_{p}}\right)-I
\end{aligned}
$$


University of Thi-Qar Journal Vol.12 No.2 June 2017

Web Site: https://jutq.utq.edu.iq/index.php/main

Email: journal@jutq.utq.edu.iq

$$
\text { pars }=\left\{I_{o}, R_{s}, R_{p}, a\right\}
$$




\section{University of Thi-Qar Journal Vol.12 No.2 June 2017 \\ Web Site: https://jutq.utq.edu.iq/index.php/main \\ Email: journal@jutq.utq.edu.iq}

\section{Review of EM Algorithm}

Electromagnetism-like algorithm is a method suggested by Birbil and Fang for the optimization purpose [14]. It is a mechanism utilizing the attraction-repulsion principle of electromagnetism theory [15]. EM is regarded as an algorithm based on the population [16]. It shares similarities with the algorithms of ant colony and particle swarm. This is because that in the population, the particles will affect one another $[17,18]$. Electromagnetism-like algorithm remains a suitable selection for dealing with continuous problems. It guesses a solution at a pace that is much quicker than other algorithms [19], at reasonably high accuracy levels [20,21]. The algorithm is classified into four distinct phases, which are:

\subsection{Initialization}

$m$ points with $n$ coordinates are randomly generated in the population. After that, the population is distributed uniformly between the upper and lower bounds [22]. For each sample, an objective function could be evaluated post-sample generation within the population.

\subsection{The Phase of Searching Locally}

Local search is defined as the process of looking for a superior solution via the gathering of localized data from each particle. Algorithm 1 points out the procedures of the searching locally [20], where, $m$ is assigned as size of the population, $n$ is the coordinates of the particle; Lsiter represents the iterations of local search, and $\delta$ is the parameter of local search, with a probability value between 0 and 1 . The algorithm starts by the local search procedure, post- initialization of the population. The first step in this algorithm is to calculate and determine the maximum feasible step length (Length) via the parameter $\delta$ (line 1). The second step analyzes every $i$, where the initial particle pars $i$ is kept within the temporary point $y$. Third, $y$ moves based on its randomly selected number coordinate- by-coordinate (lines 6-13). Fourth, in cases where the new $y$ fares better than pars ${ }^{i}$ within the Lsiter iterations, pars $^{i}$ will be replaced by $y$, and the search will terminate. If this does not occur, the counter increases a step, and the loop is restarted for another Lsiter iteration. Finally, pars ${ }^{\text {best }}$ is updated (line 22), and it is the sample point that contains the best objective function [18]. 


\section{University of Thi-Qar Journal Vol.12 No.2 June 2017 \\ Web Site: https://jutq.utq.edu.iq/index.php/main \\ Email: journal@jutq.utq.edu.iq}

\section{Algorithm 1. Local}

1. Length $\leftarrow \delta\left(\max _{k}\left\{u_{k}-l_{k}\right\}\right)$

2. For $i=1$ To $m$ do

3. For $k=1$ To $n$ do

4. Counter $\leftarrow 1$

5. DO

6. $\lambda_{1} \leftarrow U(0,1)$

7. $y \leftarrow$ pars $^{i}$

8. $\lambda_{2} \leftarrow U(0,1)$

9. If $\lambda_{1}>0.5$ then

10. $y_{k} \leftarrow y_{k}+\lambda_{2} *$ Length

11. Else

12. $y_{k} \leftarrow y_{k}-\lambda_{2}^{*}$ Length

13. End if

14. If $\operatorname{Obj}(y)<O b j\left(\right.$ pars $\left.^{i}\right)$ then

15. pars $^{i} \leftarrow y$

16. Counter $\leftarrow$ Lsiter -1

17. End if

18. Counter $\leftarrow$ counter +1

19. Loop while counter $<$ Lsiter

20. End for

21. End for

22. pars $^{\text {best }} \leftarrow \arg \min \left\{\operatorname{Obj}\left(\right.\right.$ pars $\left.\left.^{i}\right), \forall i\right\}$

4.3 The Calculation of Force and Charge of Particle

The charge needs to be determined first for each point on the sample, and for each generation, all of which are based on the function of the best particle and this particle, as detailed in the equation (9) [20]:

$$
q^{i}=\exp \left\{-n \frac{\operatorname{Obj}\left(\text { pars }^{i}\right)-O b j\left(\text { pars }^{\text {best }}\right)}{\sum_{k=1}^{m}\left[\operatorname{Obj}\left(\text { pars }^{k}\right)-O b j\left(\text { pars }^{\text {best }}\right)\right]}\right\}, \forall i
$$




\section{University of Thi-Qar Journal Vol.12 No.2 June 2017 \\ Web Site: https://jutq.utq.edu.iq/index.php/main \\ Email: journal@jutq.utq.edu.iq}

where $\operatorname{Obj}\left(\operatorname{pars}^{i}\right)$ is the objective of particle $\operatorname{pars}^{i}$, and $\operatorname{Obj}\left(\right.$ pars $\left.^{\text {best }}\right)$ is the objective of the current best particle. It should also be pointed out that the charge on a point particle lacks a sign. Alternatively, the direction of a specific force between two particles is pointed out post-comparison of the objective function value for the point [20]. Thus,

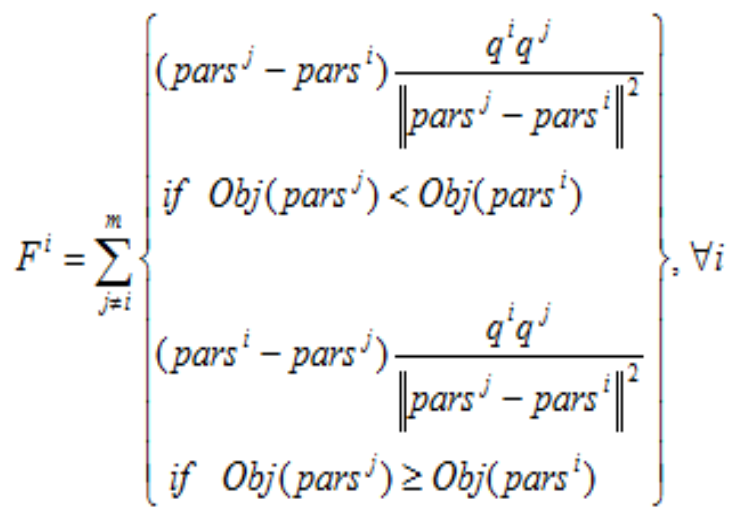

where $F^{i}$ is the overall force applied on particle $\operatorname{pars}^{i}$. A particle possessing better objective functions will inevitably attract other particles, which is also true for the opposite case.

\subsection{The Movement}

The last step, post-force evaluation, is the calculation of the movement based on the pre-determined force. The particle will update its own path based on the direction of the force through a randomized step length. The sample's point will then move towards the upper bounds when the force is positive, and vice versa [23] (Algorithm 2, lines 7-11). 


\section{University of Thi-Qar Journal Vol.12 No.2 June 2017 \\ Web Site: https://jutq.utq.edu.iq/index.php/main \\ Email: journal@jutq.utq.edu.iq}

\section{Algorithm 2. Movement}

1. For $i=1$ To $m$ do

2. If $i \neq$ best then

3. $\lambda \leftarrow U(0,1)$

4. Norm calculation for the force $\left\|F^{i}\right\|$

5. $\quad F^{i} \leftarrow \frac{F^{i}}{\text { norm }}$

6. For $k=1$ To $n$ do

7. If $F_{k}^{i}>0$ then

8. $\operatorname{pars}_{k}^{i} \leftarrow \operatorname{pars}_{k}^{i}+\lambda F_{k}^{i}\left(u_{k}-\operatorname{pars}_{k}^{i}\right)$

9. Else

10. $\operatorname{pars}_{k}^{i} \leftarrow \operatorname{pars}_{k}^{i}+\lambda F_{k}^{i}\left(\operatorname{pars}_{k}^{i}-l_{k}\right)$

11. End if

12. End for

13. End if

14. End for

Four parameters have been extracted for the photovoltaic module using the EM algorithm with Visual Basic. Net software. The limits of these parameters are listed in table 1 [13]. In this paper, the aim is to examine and test the common control parameters in the optimization algorithm as well as the $\delta$ of the EM algorithm. Then the best group of these parameters can be used to extract the PV parameters. Therefore, five cases are utilized and compared, which include the population size (popsize), the number of generations (number of iterations), and the parameter. All the results are introduced in tables 2 and 3. Table 2 gives the values of five samples of parameters. One case has been taken with less population size to see the effect of reducing this parameter. Another case with less number of iterations is also taken in this study. However, the reduction in the size of population and the iterations number will usually reduce the execution time of the 


\section{University of Thi-Qar Journal Vol.12 No.2 June 2017 \\ Web Site: https://jutq.utq.edu.iq/index.php/main \\ Email: journal@jutq.utq.edu.iq}

algorithm, but on the other hand will reduce the accuracy as in table 3. The difference between the cases 1, 4 and 5 just the local search parameter has been changed. This parameter has an obvious influence on the objective function [23].

Table 1: The boundary of the parameters

\begin{tabular}{|c|c|c|}
\hline Parameter & Lower bound & Upper bound \\
\hline$I_{o}(\mu A)$ & 0 & 50 \\
\hline$R_{s}(\Omega)$ & 0 & 2 \\
\hline$R_{p}(\Omega)$ & 0 & 2000 \\
\hline$a$ & 1 & 50 \\
\hline
\end{tabular}

Table 2: The values of the five cases

\begin{tabular}{|c|c|c|c|}
\hline Case & Popsize & Number of iterations & $\delta$ \\
\hline 1 & 50 & 300 & 0.1 \\
\hline 2 & 5 & 300 & 0.1 \\
\hline 3 & 50 & 10 & 0.1 \\
\hline 4 & 50 & 300 & 0.001 \\
\hline 5 & 50 & 300 & 0.00001 \\
\hline
\end{tabular}

Table 3: Comparison among different cases for the PV module

\begin{tabular}{|c|c|c|c|c|c|}
\hline Parameter & Case 1 & Case2 & Case 3 & Case4 & Case5 \\
\hline$I_{o}(\mu \mathrm{A})$ & 7.76 & 27.5 & 21.7 & 33.1 & 23.6 \\
\hline$R_{s}(\Omega)$ & 1.10488955 & 0.887871155 & 0.92122413 & 0.772641353 & 0.72277405 \\
\hline$R_{p}(\Omega)$ & 1717.447166 & 2000 & 1384.733219 & 1195.103424 & 1996.653153 \\
\hline$a$ & 1.443224129 & 1.617248305 & 1.585526318 & 1.647959367 & 1.594972757 \\
\hline RMSE & 0.003564232 & 0.00876367 & 0.016127161 & 0.01245099 & 0.021194928 \\
\hline
\end{tabular}

Figs. (2-4) illustrate the comparison between the cases in terms of the objective function. It can be seen that case1 ( popsize $=50$, number of iterations $=300, \delta=0.1)$ is superior the other cases with less error and with better speed of convergence. Fig. 3 has been drawn for ten iterations as in case 3 . 
University of Thi-Qar Journal Vol.12 No.2 June 2017

Web Site: https://jutq.utq.edu.iq/index.php/main

Email: journal@jutq.utq.edu.iq

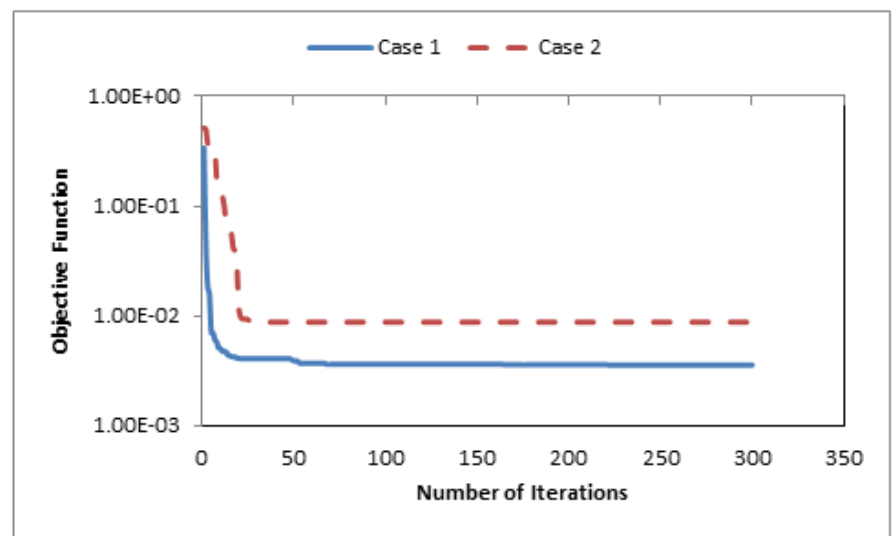

Fig. 2 Comparison of the objective function of case 2

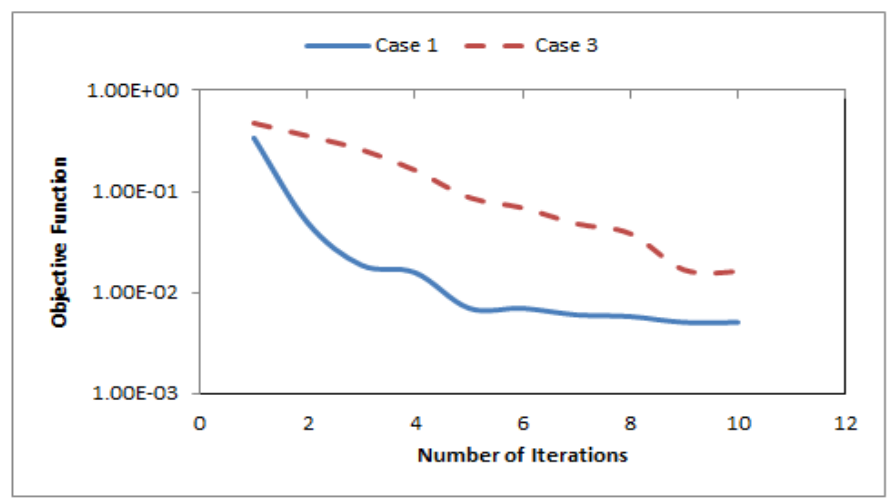

Fig. 3 Comparison of the objective function of case 3

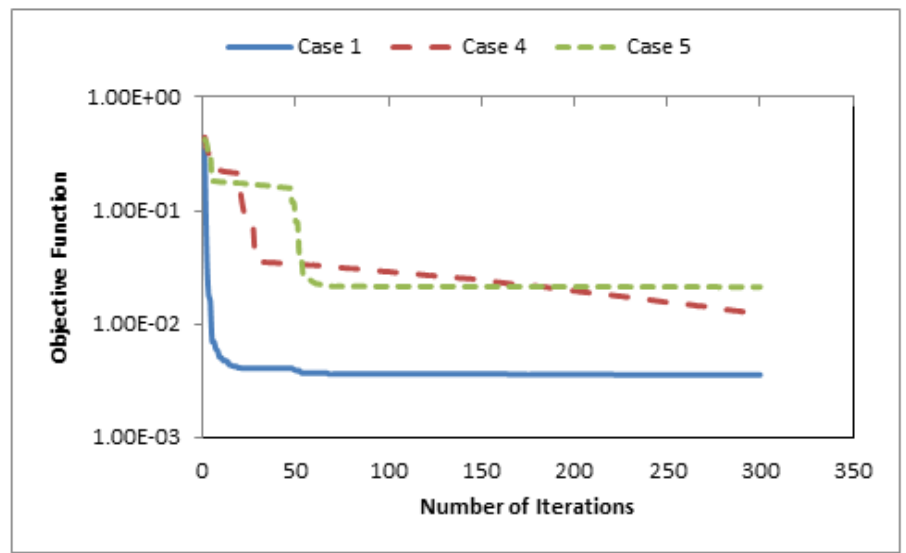




\section{University of Thi-Qar Journal Vol.12 No.2 June 2017 \\ Web Site: https://jutq.utq.edu.iq/index.php/main \\ Email: journal@jutq.utq.edu.iq}

Fig. 4 Comparison of the objective function of cases $4 \& 5$

Finally, Figs. (5-9) propose the current-voltage curves after the photovoltaic parameter identification, where the experimental data and the other PV required conditions are as in [13].

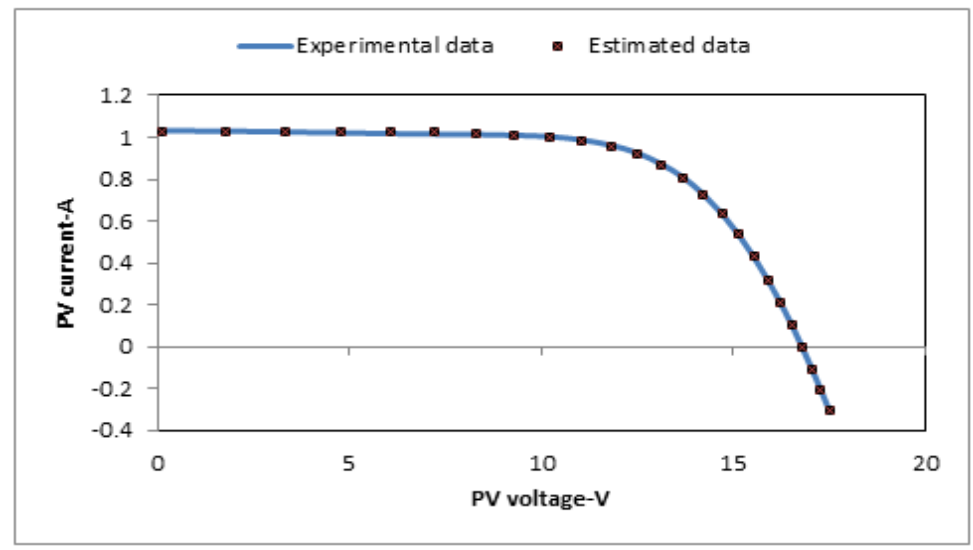

Fig. 5 Current-voltage curve for case 1

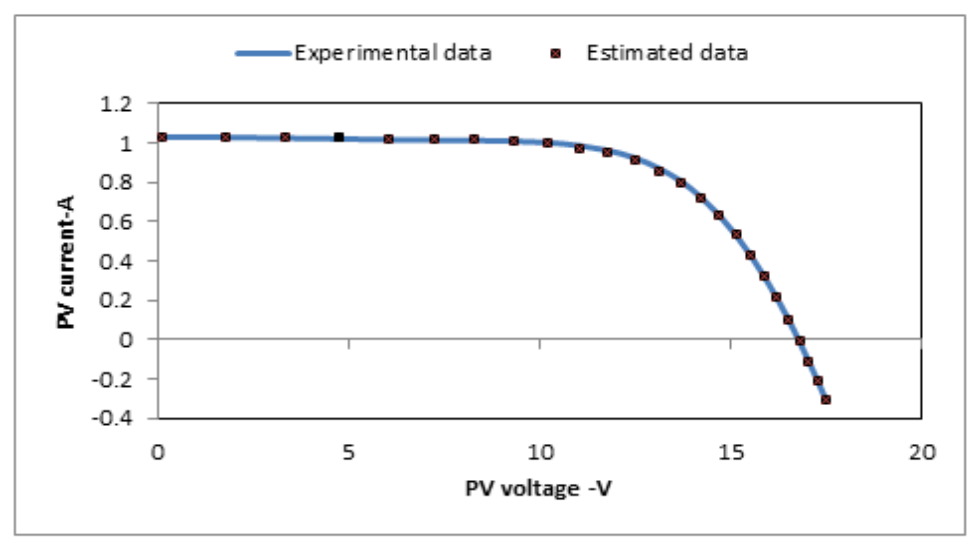

Fig. 6 Current-voltage curve for case 2 
University of Thi-Qar Journal Vol.12 No.2 June 2017

Web Site: https://jutq.utq.edu.iq/index.php/main

Email: journal@jutq.utq.edu.iq

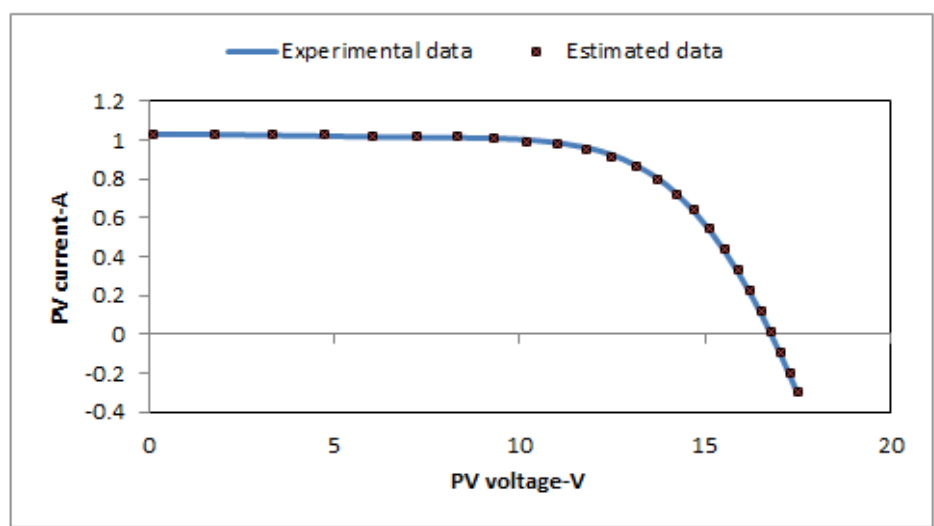

Fig. 7 Current-voltage curve for case 3

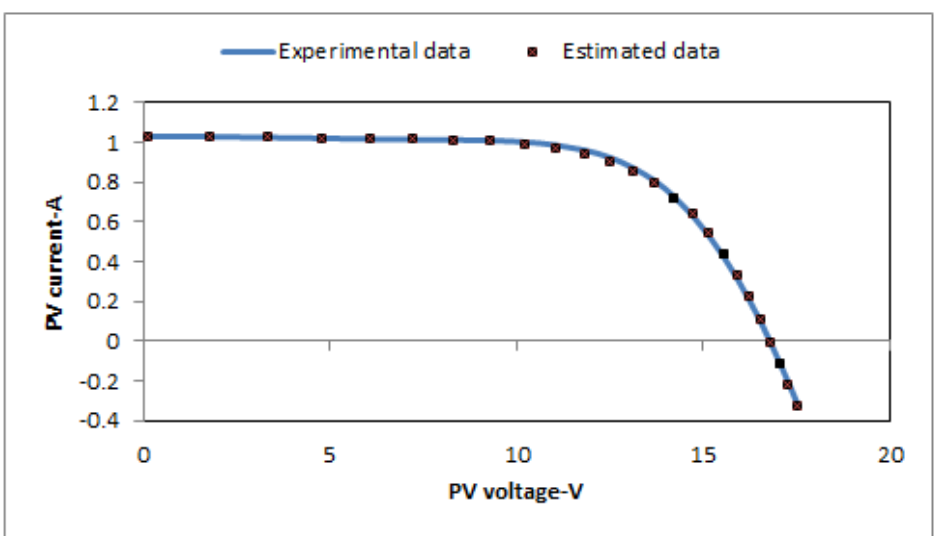

Fig. 8 Current-voltage curve for case 4




University of Thi-Qar Journal Vol.12 No.2 June 2017

Web Site: https://jutq.utq.edu.iq/index.php/main

Email: journal@jutq.utq.edu.iq

Fig. 9 Current-voltage curve for case 5 


\section{University of Thi-Qar Journal Vol.12 No.2 June 2017 \\ Web Site: https://jutq.utq.edu.iq/index.php/main \\ Email: journal@jutq.utq.edu.iq}

\section{Conclusion}

The EM algorithm is a good optimization technique that is utilized to determine the parameters associated with the photovoltaic module. The module is made up of series and parallel resistances. In order to enhance EM's ability, different values of control parameters have been taken into account in this work. The results of the control parameters were compared in the context of the objective function in order to obtain a suitable set of parameters. This set will help the algorithm to estimate better results for the photovoltaic module. According to the results, case 1 has the best objective function which is equal to (0.0035). Increase the population size or the maximum number of iterations may impact on the accuracy, but will slow down the algorithm. As a result, the most effect comes from the number of iterations and the multiplier for neighborhood parameter and this parameter shouldn't be high or low.

\section{References}

[1] Ishaque, Kashif, Zainal Salam, Hamed Taheri, and Amir Shamsudin. "A critical evaluation of EA computational methods for Photovoltaic cell parameter extraction based on two diode model." Solar Energy 85, no. 9 (2011): 1768-1779.

[2] Ma, Tao, Hongxing Yang, and Lin Lu. "Solar photovoltaic system modeling and performance prediction." Renewable and Sustainable Energy Reviews 36 (2014): 304-315.

[3] Oliva, Diego, Erik Cuevas, and Gonzalo Pajares. "Parameter identification of solar cells using artificial bee colony optimization." Energy 72 (2014): 93-102.

[4] Askarzadeh, Alireza, and Leandro dos Santos Coelho. "Determination of photovoltaic modules parameters at different operating conditions using a novel bird mating optimizer approach." Energy Conversion and Management 89 (2015): 608-614.

[5] De Blas, M. A., J. L. Torres, E. Prieto, and A. Garcia. "Selecting a suitable model for characterizing photovoltaic devices." Renewable energy 25, no. 3 (2002): 371-380.

[6] Bonkoungou, Dominique, Zacharie Koalaga, and Donatien Njomo. "Modelling and Simulation of photovoltaic module considering single-diode equivalent circuit model in MATLAB." International journal of emerging technology and advanced engineering 3, no. 3 (2013): 493-502. 


\section{University of Thi-Qar Journal Vol.12 No.2 June 2017 \\ Web Site: https://jutq.utq.edu.iq/index.php/main \\ Email: journal@jutq.utq.edu.iq}

[7] Dzimano, Gwinyai. "Modeling of photovoltaic systems." Master thesis, The Ohio State University, 2008.

[8] Ramos Hernanz, J., J. J. Campayo Martín, I. Zamora Belver, J. Larrañaga Lesaka, E. Zulueta Guerrero, and E. Puelles Pérez. "Modelling of photovoltaic module." In International Conference on Renewable Energies and Power Quality, Granada, Spain. 2010.

[9] Ja'far Saif Edden Abdel Hafeath Jallad. "Design and Simulation of a Photovoltaic System with Maximum Power Control to Supply a Load with Alternating Current." Master thesis in Clean Energy and Energy Conservation Strategy Engineering, An-Najah National University ,2012.

[10] Oi, Akihiro. "Design and simulation of photovoltaic water pumping system." PhD diss., California Polytechnic State University, San Luis Obispo, 2005.

[11] Castaner, Luis, and Santiago Silvestre. Modelling photovoltaic systems using PSpice. John Wiley and Sons, 2002.

[12] Chouder, Aissa, Santiago Silvestre, Bilal Taghezouit, and Engin Karatepe. "Monitoring, modelling and simulation of PV systems using LabVIEW." Solar Energy 91 (2013): 337-349.

[13] Gong, Wenyin, and Zhihua Cai. "Parameter extraction of solar cell models using repaired adaptive differential evolution." Solar Energy 94 (2013): 209-220.

[14] Birbil, Ş. İlker, Shu-Cherng Fang, and Ruey-Lin Sheu. "On the convergence of a population-based global optimization algorithm." Journal of global optimization 30, no. 2-3 (2004): 301-318.

[15] Su, Chao-Ton, and Hung-Chun Lin. "Applying electromagnetism-like mechanism for feature selection." Information Sciences 181, no. 5 (2011): 972-986.

[16] Khalili, Majid, and Reza Tavakkoli-Moghaddam. "A multi-objective electromagnetism algorithm for a bi-objective flowshop scheduling problem." Journal of Manufacturing Systems 31, no. 2 (2012): 232-239.

[17] Yurtkuran, Alkın, and Erdal Emel. "A new hybrid electromagnetism-like algorithm for capacitated vehicle routing problems." Expert Systems with Applications 37, no. 4 (2010): 3427-3433.

[18] Jhang, Jhen-Yan, and Kun-Chou Lee. "Array pattern optimization using electromagnetism-like algorithm." AEU-International Journal of Electronics and Communications 63, no. 6 (2009): 491-496.

[19] Lee, Ching-Hung, Fu-Kai Chang, and Yu-Chia Lee. "An improved electromagnetism-like algorithm for recurrent neural fuzzy controller design." International Journal of Fuzzy Systems 12, no. 4 (2010): 280-290. 


\section{University of Thi-Qar Journal Vol.12 No.2 June 2017 \\ Web Site: https://jutq.utq.edu.iq/index.php/main \\ Email: journal@jutq.utq.edu.iq}

[20] Birbil, Ş. İlker, and Shu-Chering Fang. "An electromagnetism-like mechanism for global optimization." Journal of global optimization 25, no. 3 (2003): 263-282.

[21] Chang, Pei-Chann, Shih-Hsin Chen, and Chin-Yuan Fan. "A hybrid electromagnetism-like algorithm for single machine scheduling problem." Expert Systems with Applications 36, no. 2 (2009): 1259-1267.

[22] Abed, Issa Ahmed, S. P. Koh, Khairul Salleh Mohamed Sahari, S. K. Tiong, and David FW Yap. "Comparison Between Genetic Algorithm and Electromagnetism-Like Algorithm for Solving Inverse Kinematics." World Applied Sciences Journal 20, no. 7 (2012): 946-954.

[23] Abed, Issa Ahmed, S. P. Koh, Khairul Salleh Mohamed Sahari, P. Jagadeesh, and S. K. Tiong. "Optimization of the time of task scheduling for dual manipulators using a modified electromagnetism-like algorithm and genetic algorithm." Arabian Journal for Science and Engineering 39, no. 8 (2014): 6269-6285. 